\title{
PERAN KONSTITUSI NEGARA DALAM MENGAWAL BANGKITNYA KEHIDUPAN WARGA NEGARA PASCA WABAH VIRUS COVID-19
}

\author{
Al Qodar Purwo Sulistyo ${ }^{1}$ Kaharudin Putra Samudra ${ }^{2}$ \\ Program Studi Ilmu Hukum, Universitas Muhammadiyah Surabaya \\ alqodar@fh.um-surabaya.ac.id
}

\begin{abstract}
ABSTRAK
Negara dan konstitusi merupakan dua lembaga yang tidak dapat di pisahkan satu dengan lainnya. Akan tetapi, untuk dapat dikatakan secara ideal sebagai Negara konstitusional maka konstitusi negara tersebut harus memenuhi sifat-sifat dan ciri-ciri dari konstitusionalisme. Lalu berdasarkan kepentingan dan wilayah tempat tinggalnya, mereka hidup dalam keterbatasan interaksi antar sesama manusia dalam peraturan yang ada yaitu pembatasan sosial agar bisa memutus rantai penyebaran virus covid-19. Secara historis pengertian negara senantiasa berkembang sesuai dengan kondisi masyarakat yang ada pada saat itu. Pada zaman Yunani Kuno para ahli filsafat negara merumuskan pengertian negara secara beragam. Aristoteles yang hidup pada tahun 384-322 S.M., merumuskan negara dalam bukunya Politica, yang disebutnya sebagai negara polis. Konstitusi mencerminkan kehiupan politik didalam masyarakat sebagai suatu kenyataan. merupakan suatu kesatuan kaidah yang hidup dalam masyarakat yang selanjutnya dijadikan satu kesatuan kaidah yang hidup dalam masyarakat yang selanjutnya dijadikan suatu kesatuan kaidah hukum konstitusi dalam hal ini sudah mengandung pengertian yuridis. atau undang-undang dapat dianggap sebagai perwujudan dari hukum tertinggi yang harus ditaati oleh negara dan pejabat-pejabat negara sekalipun. Hal ini sesuai dengan dalil Goverment by law, not by men. Kesehatan merupakan salah satu kebutuhan manusia yang sangat vital dan telah menjadi bagian dari Hak Asasi Manusia khususnya di Indonesia. Karena merupakan bagian HAM, maka untuk menunjang pemeliharaan kesehatan tersebut dibutuhkanlah sarana dan prasarana berupa Fasilitas Kesehatan atau pelayanan kesehatan yang baik dan layak. Sebagaimana yang termaktub dalam Pasal $28 \mathrm{H}$ Undang-Undang Dasar Negara Republik Indonesia yang berbunyi: "Setiap orang berhak hidup sejahtera lahir dan batin, bertempat tinggal, dan mendapatkan lingkungan hidup yang baik dan sehat serta berhak memperoleh pelayanan kesehatan".
\end{abstract}

\section{Kata kunci : Manusia, Konstitusi, Negara}

\section{PENDAHULUAN}

Secara umum Negara dan konstitusi merupakan dua lembaga yang tidak dapat di pisahkan satu dengan lainnya. Bahkan, setelah abad pertengahan yang ditandai dengan ide demokrasi dapat dikatakan tanpa konstitusi Negara tidak mungkin terbentuk. Konstitusi merupakan dasar hukumnya suatu Negara. Dasar-dasar penyelenggaraan bernegara didasarkan pada konstitusi sebagai dasar hukum. Negara yang berlandaskan kepada suatu konstitusi dinamakan Negara konstitusional. Akan tetapi, untuk dapat dikatakan secara ideal sebagai Negara konstitusional maka konstitusi negara tersebut harus memenuhi sifatsifat dan ciri-ciri dari konstitusionalisme. Konstitusionalisme sendiri merupakan suatu ide, gagasan, atau paham. Oleh sebab itu, bahasan tentang peran negara dalam mengawal bangkitnya konstitusi negara pasca wabah virus covid-19 yang mana pada saat ini sedang melanda negara kita tercinta yakni Negara Indonesia. 
Pada awalnya seluruh umat manusia hidup berdampingan bersama dalam berbagai kelompok yang beragam latar belakang. Sebelumnya umat manusia hidup dalam sebuah keluarga. Lalu berdasarkan kepentingan dan wilayah tempat tinggalnya, mereka hidup dalam keterbatasan interaksi antar sesama manusia dalam peraturan yang ada yaitu pembatasan sosial (Sosial Distancing) agar bisa memutus rantai penyebaran virus covid-19. Semula manusia hidup dalam kesatuan sosial yang disebut dengan masyarakat dan yang pada akhirnya menjadi sebuah bangsa. Bangsa adalah kumpulan masyarakat yang membentuk suatu Negara. Oleh sebab itu, banyak sekali masyarakat yang tidak bisa beraktivitas secara normal akibat adanya Pembatasan Sosial tersebut. Sehingga banyak sekali masyarakat yang tidak bisa bekerja akibat di rumahkan oleh perusahaan dimana tempat mereka bekerja. Selain itu, banyaknya masyarakat yang kesulitan dalam mengakses fasilitas kesehatan dalam masa pandemi covid 19 ini juga menjadi masalah tersendiri yang harus diselesaikan Pemerintah.

\section{PEMBAHASAN}

\section{Pengertian Negara}

Secara historis pengertian negara senantiasa berkembang sesuai dengan kondisi masyarakat yang ada pada saat itu. Pada zaman Yunani Kuno para ahli filsafat negara merumuskan pengertian negara secara beragam. Aristoteles yang hidup pada tahun 384322 S.M., merumuskan negara dalam bukunya Politica, yang disebutnya sebagai negara polis. Yang pada saat itu masih dipahami negara dalam suatu wilayah yang kecil. Dalam pengertian itu negara disebut sebagai negara hukum, yang didalamnya terdapat sejumlah warga negara yang ikut dalam permusyawaratan (ecclesia). Oleh karena itu menurut Aristoteles keadilan merupakan syarat mutlak bagi terselenggarannya negara yang baik, demi terwujudnya cita-cita seluruh warga Negara yang ada.

Pengertian lain tentang negara dikembangkan oleh Agustinus, yang merupakan tokoh Katolik. Ia membagi negara dalam dua pengertian yaitu Civitas Dei yang artinya negara Tuhan, dan Civites Terrena atau civites Diaboli yang artinya negara duniawi. Civites Tarrena ini ditolak Oleh Agustinus, sedangkan yang dianggap baik adalah negara Tuhan atau Civies Dei. Negara Tuhan bukanlah negara dari dunia ini. Melainkan jiwanya yang memiliki oleh sebagian atau beberapa orang di dunia ini untuk mencapainya. Adapun yang melaksanakan negara adalah Gereja yang mewakili negara Tuhan bukanlah negara dari dunia ini. Melainkan jiwanya yang dimiliki oleh sebagian atau beberapa orang di dunia ini untuk mencapainya. Adapun yang melaksanakan negara adalah Gereja yang mewakili negara Tuhan. Meskipun demikian bukan berarti apa yang diluar gereja itu terasing sama seklai dari Civites Dei.

Berbeda dengan konsep penelitian Negara menurut kedua tokoh pemikir negara tersebut, Nicollo Machiavelli (1469-1527), yang merumuskan Negara sebagai negara kekuasaan, dalam bukunya 'II Prin ciple' yang dahulu merupakan buku referensi pada raja. Machiavelli memandang negara daru sudut kenyataan bahwa dalam suatu negara harus ada sesuatu yang dimiliki oleh seorang pemimpin negara atau raja. Raja sebagai pemegang kekuasaan nengara tidak mungkin hanya mengandalkan kekuasaan hanya pada suatu moralitas atau kesusilaan. Kekacauan timbul dalam suatu negara karena lemahnya kekuasaan negara. Bahkan yang lebih terkenal lagi ajaran Machiavelli. Tentang tujuan yang dapat menghalalkan segala cara. Akibat ajaran ini muncullah berbagai praktek pelaksanaan kekuasaan negara yang otoriter, yang jauh dari nilai-nilai moral. Berikut ini konsep pengertian negara modern : Roger H. Soultou, mengemukakan bahwa negara adalah alat-alat agency atau wewenang yang mengatur atau mengendalikan persoalanpersoalan bersama atas nama masyarakat. 
Karakteristik Negara Indonesia memiliki suatu identitas untuk melambangkan keagungan suatu negara. Seperti negara Indonesia yang memiliki identitas yang dapat menjadi penciri atau pembangun jati diri bangsa Indonesia. Identitas Indonesia menjadikan bangsa Indonesia sebagai pemersatu dan simbol kehormatan negara. Selain itu identitas Nasional menjadikan negara Indonesia yang bermatabat di antara negara-negara lain yang memiliki beragam kebudayaan, agama, dan memiliki jiwa toleransi maupun solidaritas yang tinggi.

\section{Pengertian Konstitusi}

Konstitusi atau undang-undang dasar (bahasa latin : constitutio) dalam negara adalah sebuah norma sistem politik dan hukum bentukan pada pemerintahan negara biasanya dikodifikasikan sebagai dokumen tertulis. Hukum ini tidak mengatur hal-hal yang terperinci, melainkan hanya menjabarkan prinsip-prinsip yang menjadi dasar bagi peraturan-peraturan lainnya. Dalam kasus bentukan negara, kontitusi memuat aturan dan prinsip-prinsip entitas politik dan hukum, istilah ini merujuk secara khusus untuk menetapkan konstitusi nasional sebagai prinsip-prinsip dasar politik, prinsip-prinsip dasar hukum termasuk dalam bentuk struktur, prosedur, wewenang dan kewajiban pemerintahan negara pada umumnya. Konstitusi merujuk umumnya merujuk pada pinjaman hak kepada warga masyarakatnya. Istilah konstitusi dapat diterapkan kepada seluruh hukum yang mendefinisikan fungsi pemerintahan negara.

Konstitusi pada dasarnya memiliki pengertian luas, yaitu keseluruhan peraturan baik tertulis maupuntidak tretulis yang mengatur secara mengikat mengenai cara penyelenggaraan suatu pemerintahan. Istilah konstitusi pada umumnya menggambarkan keseluruhan sistem ketatanegaraan suatu negara. Sistem itu berupa kumpulanm peraturan yang membentuk, mengatur atau memenuhi negara. Peraturan perundang-undangan tersebut ada yang tretulis sebagai keputusan badan yang berwenang dan ada yang tidak tertulis yang berupa kebiasaan dalam praktik penyelenggaraan negara. Dengan demikian, pengertian konstitusi sampai dewasa ini dapat menunjuk pada peraturan ketatanegaraan baik yang tertulis maupun tidak tertulis. Terdapat beberapa definisi konstitusi dari pada ahli, yaitu : Herman Heller, membagi pengertian konstitusi menjadi tiga yaitu :

1. Konstitusi dalam pengertian politik sosiologi. Konstitusi mencerminkan kehiupan politik didalam masyarakat sebagai suatu kenyataan.

2. Konstitusi merupakan suatu kesatuan kaidah yang hidup dalam masyarakat yang selanjutnya dijadikan satu kesatuan kaidah yang hidup dalammasyarakat yang selanjutnya dijadikan suatu kesatuan kaidah hukum konstitusi dalam hal ini sudah mengandung pengertian yuridis.

3. Konstitusi atau undang-undang dapat dianggap sebagai perwujudan dari hukum tertinggi yang harus ditaati oleh negara dan pejabat-pejabat negara sekalipun. Hal ini sesuai dengan dalil "Goverment by law, not by men" ( pemerintahan berdasarkan hukum, bukan oleh manusia).

Pada permulaan abad ke-19 dan awal abad ke 20, gagasan mengenai konstitusionalisme, (kekuasaan terbatas dan jaminan hak dasar warga negara). Mendapatkan perumusan secara yuridis.

\section{Peran Konstitusi Negara dalam mengawal bangkitnya Kehidupan Warga Negara Pasca Wabah Covid-19}

Kesehatan merupakan salah satu kebutuhan manusia yang sangat vital dan telah menjadi bagian dari Hak Asasi Manusia (HAM) khususnya di Indonesia. Karena merupakan bagian HAM, maka untuk menunjang pemeliharaan kesehatan tersebut dibutuhkanlah sarana dan prasarana berupa Fasilitas Kesehatan (Faskes) atau pelayanan kesehatan yang baik dan layak. Sebagaimana yang termaktub dalam Pasal 28H (1) 
Undang-Undang Dasar Negara Republik Indonesia (UUD NRI 1945) yang berbunyi: "Setiap orang berhak hidup sejahtera lahir dan batin, bertempat tinggal, dan mendapatkan lingkungan hidup yang baik dan sehat serta berhak memperoleh pelayanan kesehatan". Kemudian diperjelas kembali pada Pasal 34 ayat (3) UUD NRI yang berbunyi: "Negara bertanggung jawab atas penyediaan fasilitas pelayanan kesehatan dan fasilitas pelayanan umum umum yang layak".

Ketentuan dari UUD NRI 1945 tersebut menunjukkan bahwa negara memiliki kewajiban yang bersifat mutlak dan sentral dalam menunjang kelangsungan hidup manusia Indonesia dengan menyediakan fasilitas kesehatan yang baik dan layak bagi siapa saja, sebagaimana dijelaskan padal Pasal 34 ayat (2) UUD NRI 1945 bahwa "Negara mengembangkan sistem jaminan sosial bagi seluruh rakyat dan memberdayakan masyarakat yang lemah dan tidak mampu sesuai dengan martabat kemanusiaan". Hal ini bermakna bahwa dalam hal pemenuhan hak atas kesehatan masyarakat Indonesia tidaklah bersifat diskriminatif, karena harus memperlakukan setiap orang sama dalam menerima manfaat dari fasilitas pelayanan kesehatan tersebut. Sebagai derivasi dari UUD NRI 1945, pada Pasal 8 Undang-Undang Nomor 39 Tahun 1999 tentang Hak Asasi Manusia (UU HAM) disebutkan bahwa: "Perlindungan, penegakan, dan pemenuhan hak asasi manusia menjadi tanggung jawab pemerintah". Hal ini menunjukkan bahwa konsitusi Indonesia bukan saja sebagai hukum tertinggi di negeri insulinde, tetapi juga merupakan perwujudan perlindungan hak asasi manusia dalam konteks kesehatan.

Seiring dengan perkembangan dan dinamika kekuasaan yang terjadi, lambat laun amanat konstitusi tersebut akhirnya mulai diterapkan. Terbukti pada tahun 2011 telah dibentuk Badan Penyelenggara Jaminan Sosial (BPJS) berdasarkan Undang-Undang Nomor 24 Tahun 2011 tentang Badan Penyelenggara Jaminan Sosial (UU BPJS) yang hingga hari ini masih berfungsi. Pada awal tahun 2014, BPJS Kesehatan mulai dioperasikan berdasarkan Pasal 60 ayat (1) UU BPJS yang berbunyi: "BPJS Kesehatan mulai beroperasi menyelenggarakan program jaminan kesehatan pada tanggal 1 Januari 2014". Di sinilah awal mula BPJS Kesehatan menunjukkan taringnya dalam menyelenggarakan jaminan kesehatan sosial untuk seluruh penduduk di Indonesia.

Seperti yang diketahui bersama, Indonesia saat ini mengalami suatu tekanan yang luar biasa dalam menangani Covid-19, hal tersebut dibuktikan dengan diterbitkannya Keputusan Presiden Nomor 11 Tahun 2020 tentang Penetapan Kedaruratan Kesehatan Masyarakat Corona Virus Disease 2019 (Covid- 19). Berdasarkan data terakhir, menunjukkan bahwa hingga 1 Juni 2020 kasus Covid-19 sebanyak 26.940 (positif), 17.662 (Dirawat), 1.641 (meninggal) dan 7.637 (Sembuh). Jumlah tersebut merupakan akumulasi dari sejumlah kasus Covid-19 yang terjadi di seluruh wilayah Indonesia.

Terdapat suatu dilematika yang terjadi hari ini bahwa Covid-19 tidak menjadi bagian dari jaminan kesehatan oleh Badan Penyelenggara Jaminan Sosial (BPJS) Kesehatan. Hal ini dikarenakan, Covid-19 terjadi dengan sangat cepat dan menyerupai Kejadian Luar Biasa (KLB)/wabah. Sebagaimana yang diketahui bersama bahwa dalam ketentuan Pasal 52 ayat (1) huruf o Peraturan Presiden Nomor 82 Tahun 2018 tentang Jaminan Kesehatan menyebutkan "Pelayanan kesehatan yang tidak dijamin meliputi: ... pelayanan kesehatan akibat bencana pada masa tanggap darurat, kejadian luar biasa/wabah". Tentunya ketentuan tersebut memiliki alasan yang logis, yakni bahwa anggaran terkait penanganan penyakit ketika terjadi KLB diambil alih secara komprehensif oleh Pemerintah. Akan tetapi, dengan melihat fakta yang terjadi hari ini Pemerintah mengalami kesulitan dalam penganggaran terkait Covid-19, khususnya dalam penyediaan Alat Pelindung Diri (APD) dan penjaminan kebutuhan masyarakat pada saat diterapkan kebijakan Pembatasan Sosial Berskala Besar (PSBB). 
Perlu dipahami terlebih dahulu pengertian dari KLB/wabah tersebut. Sebagaimana diuraikan dalam Peraturan Menteri Kesehatan Nomor 1501/MENKES/PER/X/2010 tentang Jenis Penyakit Menular Tertentu yang dapat Menimbulkan Wabah dan Upaya Penanggulangan, bahwa "Kejadian Luar Biasa yang selanjutnya disingkat KLB, adalah timbulnya atau meningkatnya kejadian kesakitan dan/atau kematian yang bermakna secara epidemiologi pada suatu daerah dalam kurun waktu tertentu, dan merupakan keadaan yang dapat menjurus pada terjadinya wabah". Kemudian dijelaskan pula dalam ketentuan tersebut bahwa "wabah penyakit menular yang selanjutnya disebut Wabah, adalah kejadian berjangkitnya suatu penyakit menular dalam masyarakat yang jumlah penderitanya meningkat secara nyata melebihi dari pada keadaan yang lazim pada waktu dan daerah tertentu serta dapat menimbulkan malapetaka". Jika dilihat dari ketentuan tersebut terdapat suatu kesesuaian keadaan antara cepatnya penularan Covid-19 dengan pengertian dari wabah tersebut yang merupakan bukan bagian dari jaminan kesehatan oleh BPJS.

Dilematik antara konstitusionalitas jaminan kesehatan dengan Perpres Jaminan Kesehatan memang kian pelik ketika diarahkan dalam konteks kekinian. Antara kebutuhan Rumah Sakit dan kebutuhan sosial akibat PSBB tidak mengalami penanganan yang cukup signifikan. Sebagai contoh, RS Jasa Kartini sebagai salah satu RS yang menjadi rujukan pasien Covid-19 mengalami kekurangan APD (Sumber: https://www.cnnindonesia.com/, 3 April 2020). Di sisi lain, dengan adanya kebijakan PSBB oleh Pemerintah melalui Peraturan Pemerintah Nomor 21 Tahun 2020 tentang Pembatasan Sosial Berskala Besar dalam Rangka Percepatan Penanganan Corona Virus Disease 2019 (Covid-19) menimbulkan keresahan dikalangan masyarakat sipil. Bagaimana tidak, Pemerintah dituntut agar dalam PSBB ini dapat memberikan bantuan kebutuhan kehidupan sehari-hari bagi masyarakat, karena hampir seluruh kegiatan kerja dilakukan di rumah (work from home) sehingga pendapatan masyarakat mengalami penurunan khususnya bagi pekerja serabutan atau harian. Pada konteks yang lain, Pemerintah juga kewalahan dalam menyediakan APD meskipun telah diterbitkan Peraturan Pemerintah Pengganti Undang-Undang Nomor 1 Tahun 2020 tentang Kebijakan Keuangan Negara dan Stabilitas Sistem Keuangan untuk Penanganan Pandemi Corona Virus Disease 2019 (Covid-19) dan/atau dalam Rangka Menghadapi Ancaman yang Membahayakan Perekonomian Nasional dan/atau Stabilitas Sistem Keuangan. Dalam Pasal 1 ayat (3) Perpu tersebut diuraikan bahwa "Untuk melaksanakan Anggaran Pendapatan dan Belanja Negara (APBN) sebagaimana dimaksud pada ayat (1) dan ayat (2) dalam rangka: Penanganan pandemi Corona Virus Disease 2019 (COVID-19) dan/atau menghadapi ancaman yang membahayakan perekonomian nasional dan/atau stabilitas sistem keuangan”.

Pemerintah Daerah juga diberikan kewenangan untuk menggunakan anggaran melakukan pengutamaan penggunaan alokasi anggaran untuk kegiatan tertentu (refoatsing), perubahan alokasi, dan penggunaan Anggaran Pendapatan dan Belanja Daerah. Sinergitas antara APBN, APBD dan jaminan kesehatan oleh BPJS sangat diperlukan. Peraturan Presiden Nomor 82 Tahun 2018 tentang Jaminan Kesehatan memang tidak meng-cover untuk dalam hal penanganan Covid-19/wabah/KLB. Tetapi dengan diskresi melalui Peraturan Presiden yang membahas khusus keterlibatan BPJS dalam penanganan Covid-19 bisa saja menjadi jalan agar kebijakan sebelumnya dilampaui. Sehingga pasien Covid-19 bisa ditangani dengan menggunakan anggaran BPJS, yang pada dasarnya mampu membantu Pemerintah dalam mengakomodir Rumah Sakit yang ditunjuk melalui BPJS serta alokasi dana Pemerintah dalam memberikan bantuan kepada masyarakat dapat terdistribusi lebih efektif dan merata. Memang bukan 
merupakan perkara yang mudah, namun dengan tetap menjaga konstitusionalitas jaminan kesehatan terhadap seluruh warga negara Indonesia, maka pengentasan Covid-19 dapat terlaksana dengan baik. Pada akhirnya, BPJS hebat jika mampu bermanfaat bagi seluruh rakyat Indonesia.

Sudah saatnya BPJS menjadi badan yang lebih luas lagi fungsinya, yang awalnya hanya pada fungsi penganggaran dan pengorganisasian dalam hal pelayanan kesehatan, tetapi jika BPJS berani mengambil andil dalam situasi dan kondisi hari ini, maka BPJS dapat menjadi pahlawan kemanusiaan. Sebab isu Covid-19 bukan saja di Indonesia, tetapi telah menjadi pandemi internasional. Selain itu, masyarakat juga akan merasa tertolong dengan uang yang telah dibayarkan ke BPJS jika dimanfaatkan bagi orang yang terdampak Covid-19 melalui fasilitas pelayanan kesehatan yang memadai tanpa memperhatikan kelas-kelas tertentu.

\section{Perlunya Peran Konstitusi Negara dalam Mengawal Bangkitnya Kehidupan Warga Negara Pasca Wabah Covid-19}

"Kemudian dari pada itu untuk membentuk suatu Pemerintahan Negara Indonesia yang melindungi segenap bangsa Indonesia dan seluruh tumpah darah Indonesia, dan untuk memajukan kesejahteraan umum..." (Preambule/Pembukaan UUD 1945). Demikianlah bunyi pembukaan UUD 1945. Begitulah perjanjian luhur berdirinya bangsa dan negara Indonesia. Artinya negara mempunyai tanggungjawab konstitusional untuk melindungi seluruh "tumpah darah Indonesia". Itulah kesepakatan agung dan meta-norm yang mesti diwujudkan! Apakah negara melalui organnya yang bernama pemerintah telah memberikan perlindungan maksimal sebagaimana amanat konstitusi tersebut?

Virus corona yang bermula dari episentrum corona yaitu Kota Wuhan, Provinsi Hubei di Cina dan sangat mematikan itu telah menyebar hampir di seluruh penjuru dunia termasuk Indonesia tercinta. Bahkan organisasi WHO telah menyatakan bahwa corona merupakan pandemik dan Sekjen WHO meminta kepada Presiden RI Jokowi untuk menetapkan status darurat terhadap wabah corona di Indonesia. Dikatakan sebagai pandemik karena penyebaran wabah corona sangat cepat dan meluas di berbagai belahan dunia. Jadi sifatnya mengglobal, bukan lagi nasional.

Sayangnya sejak awal para pemangku kebijakan di tanah air pernyataannya banyak yang saling berbenturan, meskipun pada akhirnya pemerintah menetapkan status wabah corona sebagai Bencana Nasional. Tapi awalnya, beberapa pejabat negara dan elite di negeri ini merasa pede seolah-olah virus corona tidak akan sampai ke tanah air. Tapi fakta berkata lain dan ini pelajaran yang sangat berharga! Pada 2 Maret 2020 Indonesia secara resmi kemudian mengakui merebaknya COVID-19 dimana Presiden Jokowi mengumumkan 2 pasien pertama yang terkena COVID-19. Malahan saat ini death rate Indonesia terkait COVID-19 menduduki peringkat kedua di dunia.

Yang diperlukan saat ini adalah konsistensi strategi dalam menghadapi pandemik global ini. Jadi tidak boleh berjalan sendiri-sendiri yang tidak terintegrasi. Dari pemerintahan pusat, daerah maupun sampai ke tingkat kelurahan dan RT. Informasi untuk pencegahan wabah corona harus bersifat transparan, masyarakat harus mengetahuinya sehingga ada upaya kolektif untuk meminimalisasi penyebaran wabah corona. Pejabat tidak boleh berpendapat sekenanya terkait COVID-19 bila tidak memiliki kompetensi terutama yang terkait medis. Informasi dari pemerintah harus solid, integratif dan solutif.

Masyarakat tidak membutuhkan perdebatan dan silang pendapat yang kontraproduktif. Masyarakat juga harus kompak, saling membantu serta berusaha dengan segala kekuatan yang dimiliki untuk membendung semakin menyebarnya virus corona yang mematikan itu. Transparansi seperti ini adalah bagian dari tanggungjawab pemerintah kepada publik, sebab masyarakat memiliki hak untuk mendapatkan informasi kesehatan 
yang akurat dan benar (right to obtain information). Masyarakat juga memiliki hak untuk dilindungi (right to be protected), hak untuk dipenuhi hak-hak kesehatannya (right to fulfill) dan sebagainya. Ini adalah hak konstitusional warga negara, dan merupakan kewajiban konstitusional negara. Hal ini sudah jelas disebutkan dalam pembukaan UUD 1945 dimana negara mempunyai kewajiban melindungi "seluruh tumpah darah Indonesia". Konsekuensinya negara harus menyampaikan kepada publik apa rencana, langkah dan strategi kebijakan yang telah dan akan dilakukan, bagaimana regulasinya, simulasinya, penanganan dampaknya, berapa dana yang disediakan, dan kemungkinan terburuk lainnya.

\section{KESIMPULAN}

Secara historis pengertian negara senantiasa berkembang sesuai dengan kondisi masyarakat ada saat itu. Pada zaman Yunani Kuno para ahli filsafat negara merumuskan pengertian negara secara beragam. Aristoteles yang hidup pada tahun 384-322 S.M., merumuskan negara dalam bukunya Politica, yang disebutnya sebagai negara polis. Konstitusi atau undang-undang dasar (bahasa latin : constitutio) dalam negara adalah sebuah norma sistem politik dan hukum bentukan pada pemerintahan negara biasanya dikodifikasikan sebagai dokumen tertulis. Hukum ini tidak mengatur hal-hal yang terperinci, melainkan hanya menjabarkan prinsip-prinsip yang menajdi dasar bagi peraturan-peraturan lainnya.

Keadilan dalam bidang pelayanan kesehatan adalah suatu hal mutlak yang harus diperjuangkan oleh para penguasa dan wakil rakyat untuk menciptakan kesejahteraan sosial secara komprehensif dan masif. Sebab keadilan adalah to render to each man what is his due (memberikan kepada setiap orang apa yang semestinya). Dan melindungi diri sendiri merupakan hak, namun melindungi sesama manusia adalah kewajiban moral bagi seluruh umat manusia. Semua itu adalah kewajiban konstitusional pemerintah. Pemerintah harus bertanggungjawab, kebijakan harus dibuat terbuka, transparan serta maksimal dalam menghadapi krisis dan wabah corona yang belum pernah terjadi sebelumnya dalam sejarah ini (unprecedented outbreak).

Berdasarkan hasil kesimpulan diatas pada kesemapatan kali ini, saya menyatakan sangat di perlukannya peran pemerintah negara dalam penanganan wabah covid-19 yang sedang melanda negara kita pada saat ini. Dalam mengbangkitkan konstitusi negara juga di perlukan peran pemerintah serta masyarakat indonesia guna memulihkan kembali situasi dan kondisi pasca menyebarnya wabah virus covid-19. Sebab, tanpa campur tangan masyarakat pemerintah tidak akan pernah bisa menyelesaikan atau menangani wabah tersebut. Peran masyarakat juga sangat di perlukan guna memutus mata rantai penyebaran covid-19 dengan menjaga jarak, memakai masker jika keluar rumah, serta mencuci tangan dengan sabun/anti septik sesering mungkin.

\section{DAFTAR BACAAN}

Effendi Suryani \& Kaswan. (2015). Pancasila dan Ketahanan Jati Diri Bangsa. Bandung: PT Refika Aditama.

Kaelan. (1980). Pendidikan Kewarganegaraan untuk Perguruan Tinggi. Yogyakarta: Paradigma.

Kompas. (2020, Juni 1). Data Covid-19 Di Indonesia. Retrieved from Kompas.com: https://www.kompas.com/covid-19

Kusnardi, M. (1980). Pengantar Hukum Tata Negara Indonesia. Jakarta: FHUI.

Lubis, M. A. (2018). Pembelajaran Ppkn Di SD/MI. Medan: AKASHA SAKTI. 
